\title{
Concept of Sharing Space in the Spatial Conflict of Urban Kampong an Ethnography Study in Bustaman Semarang
}

\author{
1Budi Sudarwanto, 2Atiek Suprapti, 3Gagoek Hardiman,4Agung Budi Sardjono
}

1Architecture Department, Faculty of Engineering, Diponegoro University, Semarang, Indonesia. 2Architecture Department, Faculty of Engineering, Diponegoro University, Semarang, Indonesia 3Architecture Department, Faculty of Engineering, Diponegoro University, Semarang, Indonesia 4Architecture Department, Faculty of Engineering, Diponegoro University, Semarang, Indonesia

Correspondence Author: Budi Sudarwanto, Architecture Department, Faculty of Engineering, Diponegoro University, Semarang, Indonesia E-mail:budisud@gmail.com

Received date: 29 August 2019, Accepted date: 25 November 2019, Online date: 26 November 2019

Copyright: (C) 2019 Budi Sudarwanto et al., This is an open-access article distributed under the terms of the Creative Commons Attribution License, which permits unrestricted use, distribution, and reproduction in any medium, provided the original author and source are credited.

\begin{abstract}
This study aims to describe the kampong spaces for the uniqueness activities of Bustaman that still exist on the process of urbanization. Urbanization had an influence on changes in the physical environment of a city. The city of Semarang also experienced physical changes due to economic growth and government policies. Bustaman was a unique urban kampong based on its economic activities. Sharing was its label as an urban kampong with its local economic wisdom. By community's local concept of "selling without capital" motivated them running the economic activities, and made the kampong survive facing modern urbanization. Those implied to the spatial character of the kampong. This study employed a grounded theory technique. The step of analysis was done through by the qualitative research process. Analysis used several approach to examine the community's daily activities, the physical environment, and their culture like 'holistic' approach, 'comprehensive' approach, a nd 'critical' approach. Findings revealed that the components of sharing in local economic activities had a series of linkages, including shared roles, activities, places, results, time, and capital. The characters of the spatial structure and the local economic space of the kampong were spontaneous, unstructured and compact. Sharing was a keyword for survive of an urban kampong in the process of urbanization, eventhough there was a little conflict on the reality of everyday life in the kampong.
\end{abstract}

Keywords: Urban Kampong, Bustaman, Sharing Space, Local Economy, Qualitative Research.

\section{INTRODUCTION}

Jo Santosa [1] stated that urban kampong in the globalization era experiences a defensive transformation. Setiawan [2]added that the kampong exhibits chaos and slums in the physical environment, and similarly. Roychansyah[3]was also stated that kampong spaces hows compactness, efficiency, and irregularities. Lana and Heracles[4] even Freek Colombijn[5] explained that urban kampongs had the independence to survive and they were able to develop themselves by using their local strengths. Sihombing [6] declare that urban kampong life was a complex problem of cohesion and social conflict, chaotic public areas, and physical limitations of the environment. According to the fact, Jo Santoso (2013) showed that the distinctive characteristic of urban kampong culture was on how people developed themselves based on local forces[1].

Bustaman had a unique character as an urban reality. It was very distinctive space which based on its local economic activities. The activities related to 'gule' soup (rich and spicy curry-like soup) encourage a very unique urban space. Adiyanti $S$ [7] stated the dynamics of everyday life experienced by the kampong, its make a distinctive culture which was able to survive. Sudarwanto B [8] explained the Bustaman local knowledge made it survive to urban change was sharing concept, which had meaning in economy, social, and culture to the urban kampong.

'Gule' soup as the core of local economic activities builds an internal structure of kampong spaces, and it was integrated as urban economic life. Processing and selling activities were the basic aspects of the local economy of the Kampong. On a microscale (occupancy), in the mezzo scale (kampong), and macroscale (urban) there was a flow of processing and selling of 'gule'soup. The processing and selling activities built the character of kampong that was able to survive until today. Bustaman kampong was better known as the 'gule' soup kampong for the people of Semarang today.

Desouza and Flanery[9] stated that the survival of an urban kampong was how its kampong being resistant to external factors and internal changes. Integrating activities through existing networks or even providing openness to the outside was a form of response to the defensive urban kampong. Adiyanti S \&Buchholz[7], and Poolkhetet Al[10] said the character of the urban kampong space was closely related to the culture of people who live in it. Flor AG[11], mention its characters was shown in signs, forms, and symbol that were unconsciously carried out by its inhabitant. Suprapti A [12] stated about a control spatial protection constructed by community in Kauman kampong based on the relationship among socio-cultural aspect, economic aspect, religious aspect, and political aspect. This factor makes the physical development of the kampong controlled by the citizens' convention.

Bustaman had empirical knowledge that influences life as a 'gule' soup kampong. Empirical facts and events have proven the strength of local knowledge that had not been studied. Symbols and signs as an urban kampong shown the character as a 
'gule' soup kampong. This 'gule' soup was a well-known cuisine that spreads throughout the city of Semarang. People process 'gule' soup in the terrace of houses. They took a bath in public toilets. They also ran some gathering cultural events in a public space of kampong. The local economic activities of Bustaman relate to its role as a supplier of a local 'gule' soup cuisine all over city needed enough space in their residence. However, the use of semi-public space and public space for private activities often lead to space conflicts. The question of this study is how the Bustaman community using space which was very limited in quantity and quality. Administratively, Bustaman kampong includes two littlest neighbourhoods group of RT. 04 and RT. 05 in Purwodinatan of Central Semarang District.

Bustaman knows as a unique 'gule' soup kampong. Its soup influences the reality of expressions of kampong face, its physical conditions, and the behavioural of its inhabitant. This research article explains the sharing of concepts through qualitative research. The local economic activities were differentiators in the realm of urban kampong space research. The economic culture shows the peculiarities of the urban kampong life in an effort to survive to modern times.

Henri Lefebvre[13] explained in the theory of space production that there were contradictions in the 'urban reality' and 'expression' of the daily lives of its inhabitants. Sudaryono[14] stated the kampong reflects the reality and expression of urban life in Indonesia because $60 \%$ is kampongs. The Contradiction occurred between private space (dwelling) as the first space with the public space (physical environment) as the second, and the contradiction space which was called the third space. The third space was an expression of the urban kampong space in which the expression of space was related to the culture of the kampong community. Noor Hamidah et al., [15] declared that the character of the urban kampong space were non-orderly, compact, and efficient. Maliki, NZ et al.[16] stated that the urban kampong space showed cultural expression of the community forced by the strength of locality. They further mention it was as a transitional space. Prayitno B [17]stated that as the co-habitation, space became a place for individuals to continuously carry out their activities as a collective habit.

Sudarwanto B et.al (2019) said the third space of Bustamanis a sharing places that have the core concept of knowledge: 'mangkat ndengkul mulih mikul'(selling without capital), 'pek-nggo' and 'pomah' (my neighbour my life partner and feel home), also 'kini-nanti'(sustainable for life)[8]. This was new substance knowledge in the realm of urban kampong space theory. Sharing in the economic aspect was mutual support and cooperation, lending each other cooking tools, changing places to sell, lending money without interest, and also providing assistance for those who did not have an income. Nur Huzeima MH and Hugh Byrd [18] explained the concept of 'back to the kampong' was a reality of deurbanization that occurred in Malaysia. The process of urban modernization had caused migrants to return to their homes. This was different from what happened in Indonesia such as Bustaman, its citizens survived in the reality of urbanization.

Tolerance between residents, living together in family, and togetherness in neighbours becomes the meaning of sharing in the social aspects of Bustaman kampong life. It was a place to improve the economy of life for its residents as well as visitors and even visitors. It was also an economic magnet for the surrounding villages. Although in the third space, there were still negative impacts such as business activities, community conflicts, and a decrease in the quality of space and place in the kampong life. This negative aspect becomes an obstacle for urban kampong that was difficult to repair, due to the socioeconomic conditions of the inhabitants and their culture. Rully Damayanti and Florian Kossak[19] revealed that the reality and expressions of the Bustaman were illustrated the characteristics as described earlier; this could be said to be the development of third space theory.

\section{MATERIALS AND METHODS}

The research was employed with grounded theory to find out the emotional knowledge that influences the culture of residents and the physical condition of the kampong. The basic philosophy of this technique was constructive thinking that opens the social reality of participant understanding and uses reflexivity to prevent bias. The selection of informants was carried out by 'purposive sampling'. The data were recorded as an in-depth description of the results of observations, interviews, and other text notes. Data were analyzed through an iterative process until the findings were presented.

The research unit was 1) Bustaman goat slaughterhouse, the slaughterhouses were characteristic of local economic activities. , 2) 'gedong sepuluh' in kampong area, the consideration was that 'gedong sepuluh' gave a strong occurrence as an urban kampong environment. 'Gedong sepuluh' was a high-density residential area with a low environmental quality. And 3) living area of RT.05/RW.03Bustaman. The area of RT.5/RW.3 depicts the daily living conditions of the town's village, there were several kampong artefacts from Bustaman. These three observation units were investigated and observed in depth to obtain data related to local economic activities through in-depth interviews, sketching, recording daily events.

Data was given code, analyzed and grouped, and also validated to get saturation. The process was repeated to obtain information that represents field facts. Some analytical approaches had been carried out to analyze facts and events in the field. To explore the fundamental problems was used critical thinking. A comprehensive way of thinking to analyze the linkages of the components of the urban kampong. Holistic thinking was done to draw the whole character of the kampong.

Systemic steps were taken to carry out data processing and analysis taking into account the functional, structural and critical approaches. Some empirical themes of social, economic, and cultural aspects were categorized into the concepts of local knowledge of the Bustaman. The first was 'gule' soup locality, the second was shared and future space, the third was the tension of kampong space, and the fourth was chaos and complexity. The concept of local knowledge was analyzed to obtain core knowledge substances based on unbiased empirical events. The sharing concepts theory became a core category of the substance theory with the following subcategories: 'mangkat ndengkul mulih mikul', 'pek-nggo' and 'pomah', and 'tembus tapi aman'. This conception was built from the local knowledge of its community. Sharing was new local knowledge in the urban kampong realm based on the local economic activities.

\subsection{Bustaman as an Urban Kampong.}

\section{DISCUSSION}

The physical artefacts of the kampong built the space character as an urban kampong (see Fig. 1). Gedong Sepuluh gave a characteristic of community social life in the densely populated area of the city. Javanese ethnicity and 'kujo' (Arab and Ja vanese descendants) were majority residents in the kampong. They were quite friendly and open to visitors. Slaughterhouse was a physical fact affect the uniqueness of this kampong. Ancient wells and public toilet buildings in the middle of the kampong were facilities for the community to meet their daily needs. Al - Barokah Mosque was a place for Muslims praying. Almost all residents worked as street tv endorse in front of their homes. The murals on the walls showed the expression of local economic activities and the dominant figure of Raden Saleh who was the world-famous painter in the medium of 20 'th century from Bustaman. There were communities effort to preserve the culture of the past to be a driver for the present.

Bustaman as an urban kampong in the urban centre had high population density reaching 590 residents/ha. The productive age was more than $65 \%$ (productive age: 15 to 60 years) and the main livelihoods depend on informal sector. Its distance was 
about 10 minutes from downtown Semarang. (see Fig. 1: Location of Bustaman kampong) The number of families is approximately 130 families with 456 residents. 102 of them live in Gedong Sepuluh, private parts of the kampong.
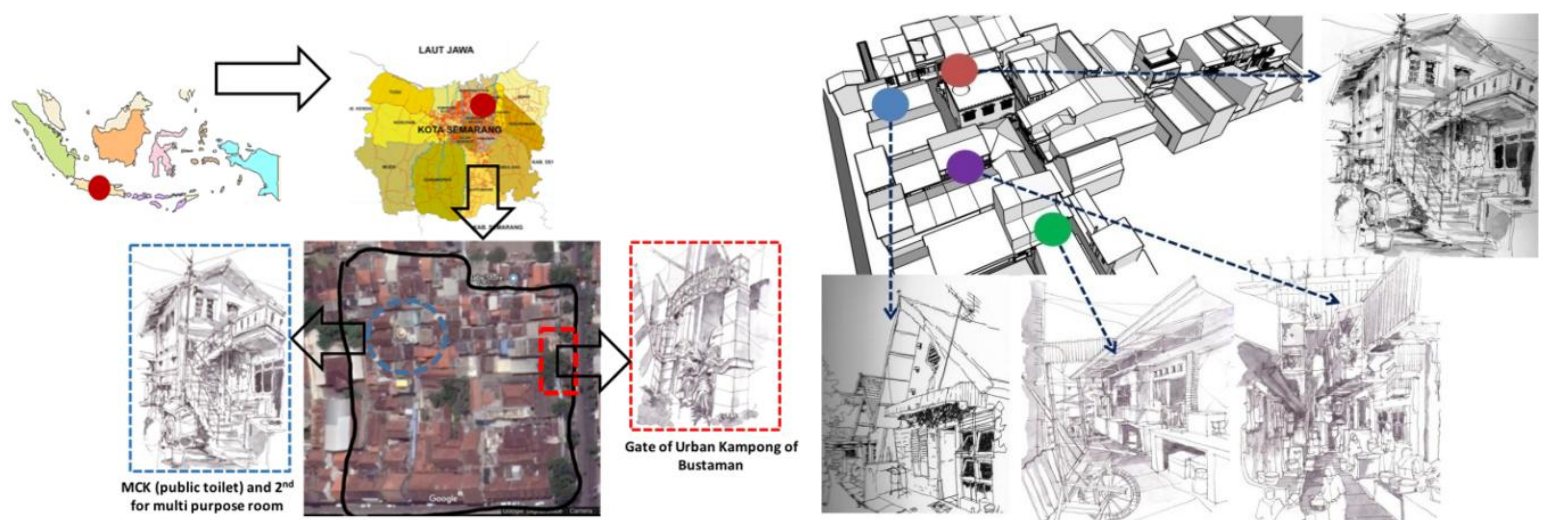

Fig. 1: The Location of Bustaman kampong and some physical artifacts. Source: field survey, 2017

The social economy condition residents could be categorized as low-income people. Most of them worked as traders and sellers of food and beverage (there were 53 residents). There were 21 employees and self-employed people and rough staff such as artisans, drivers, and craftsmen (there were 19 people). There were 11 housewives and widows. There was only one active civil servant and there were two full-time retainers. The informal sector was the main occupation of residents.

The education level was mostly highschool and only a few had a bachelor degree. Many Bustaman residents worked as informal sectors of food and beverages, such as meatball, fried food, rice, chicken noodle, beverage, etc. They opened stalls and had tables on their own terraces. In front of the former ' $R P H$ ' building was a bustling selling location. RPH were slaughterhouses built by the local government to accommodate the activities of residents who worked as slaughterers during the mid-1980s. At present the slaughterhouses no longer functioned properly and even used as warehouses and motorcycle parking.

Adiyanti $S$ and Buchols (2013) mentioned that gathering on the kampongs road and bathing in public toilets, community meet the needs of daily life by selling was an expression of urban kampong life[7]. The culture could be found in daily life in the Kampong. The activity affected the character of the space and the shape of Kampong. In accordance with the results of Maliki NZ (2014), Bustaman showed its character as an urban kampong [16]. Its physical environment showed irregular, efficient and compact characteristics. This was following the opinion of Roychansyah (2009) and Noor Hamidah (2017) who also mentioned the characters of the urban kampong space[3],[15]. Bustaman was able to survive well through the culture of urban life. During research period the unique daily life character was still running, even the more established of resilience.

This condition was in accordance to what DesouzaandFlanery (2013) stated that the resilience of a good urban kampong space run with the positive relationship between internal and external elements of kampong[9]. Bustaman was easily accessible from surrounding accesses, like 'Mataram' area as the entrance and 'Petudungan' road and small alley from 'Petolongan'. Bustaman was an economic magnetic field for the surrounding area and up to the city. The lamb was an economic commodity that only exists in this kampong and could not find in the other kampong. They sold 'gule' soup out of the kampong to some strategic locations in the city of Semarang. 'Gule' soup cuisine was very well known by the people of Semarang, for example, the 'gule' soupstall behind the Blenduk church in old city was held by Bustaman people.

Their communities activities on a micro-scale (occupancy), mezzo (kampong), and macro (urban) were integrated one and another. Bustaman gave information about the relationship between activities and places. In the micro-scale was the activity of managing the goat animals in goat slaughterhouses and house terraces. The local economic activities related to the goats became a driving force for the kampong' economic life [7], [10]. Unconsciously, they built local economic networks through family social relations. Local economic actors had family ties as descendants and heirs of previous generations. The 3rd generation was the driving force for traditional business.

This result above was different from a study of Flor AG (2001), that people unconsciously built signs, shapes and ymbols[11]. The awareness of the residents of Bustaman was mediated by a community that was sensitive to urban problems. It had a community figure, namely Mr Hari Bustaman, who always gave inspiration and enthusiasm to the living a characteristic of the kampong. The peculiarities of the kampong and its history should be maintained against the urban change.

\section{2. 'Gule' soup as LocalDishesofUniquePlace.}

'Gule' soup has a unique story. The local activities showed the ups and downs of Bustaman's life as an urban kampong. It starts in a slaughterhouse until it becomes 'gule' soup. This was the historical value of its local wisdom. There were two subsystems developed in it: processing and selling. The stages of the process were the sequence of activities concerning: 1) the goats brought from the animals market, 2) the goats kept on cage then cut in the morning next day, 3). The meat was cut and cleaned to be cooked into 'gule' soup. Selling meant to prepare everything from cooking and arranging in a cart and brought it walking to the locations outside of the kampong and will return home in the afternoon to continue other activities.

The role of residents as the actors of local economic activities was very complete and they live in it (see fig. 2). Boro as migrant traders performed their role in the sales sub-system. 


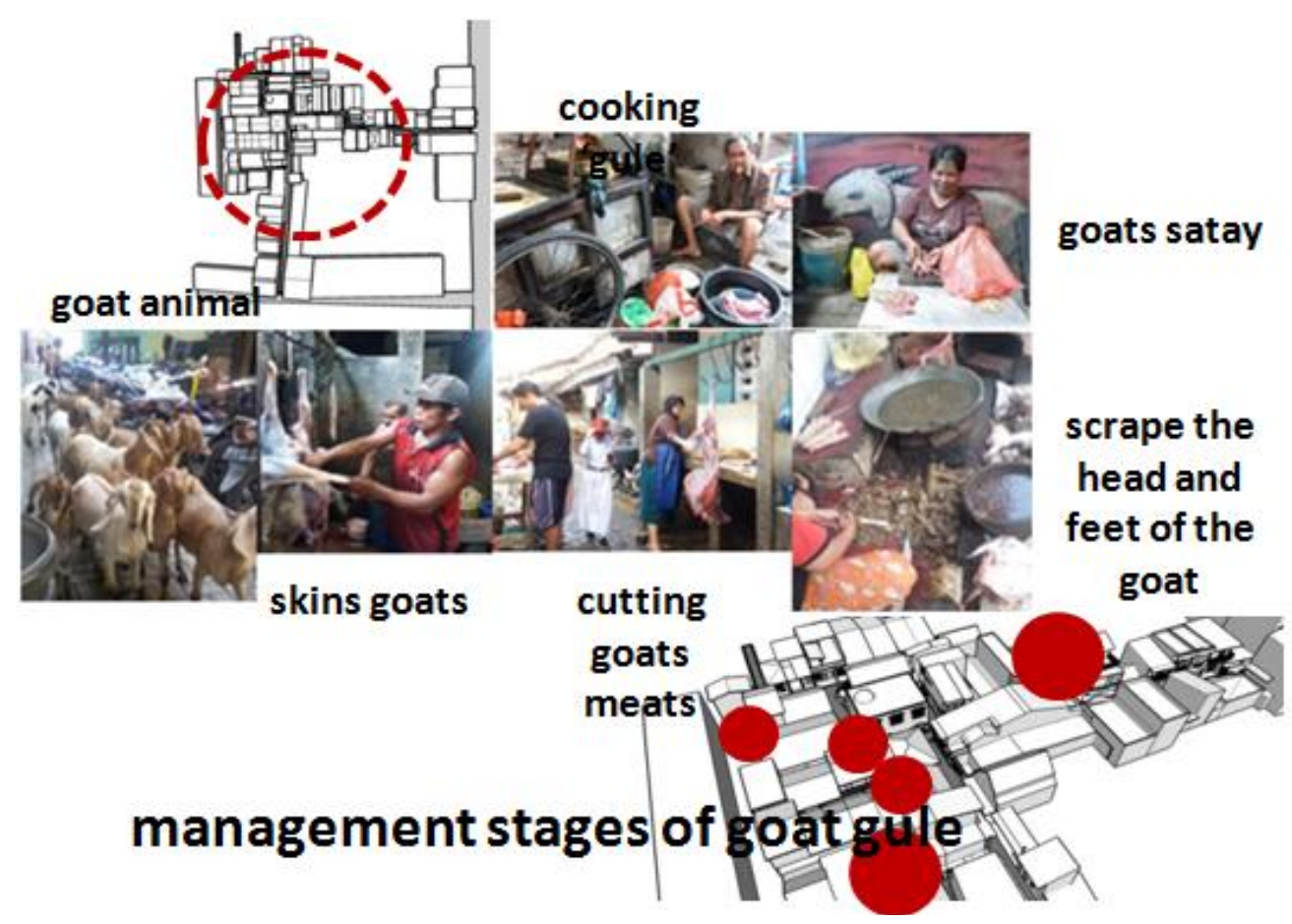

Fig. 2: The processing of 'gule' soup in Bustaman kampong. Source: field survey, 2017

Table 1: The activities, actors and its implication to space of kampong

\begin{tabular}{|l|l|l|l|l|}
\hline $\begin{array}{c}\text { No } \\
.\end{array}$ & \multicolumn{1}{|c|}{ Activities } & \multicolumn{1}{|c|}{ Actors } & \multicolumn{1}{|c|}{ The implication of space } & Notes \\
\hline 1 & $\begin{array}{l}\text { taking goats into the } \\
\text { kampong }\end{array}$ & $\begin{array}{l}\text { the blantik and } \\
\text { the butcher } \\
\text { slaughter }\end{array}$ & $\begin{array}{l}\text { the goat abattoir was less healthy and less } \\
\text { clean }\end{array}$ & healthy settings are needed \\
workers & $\begin{array}{l}\text { visually and smelly disturbed the } \\
\text { environment and made it a slum, } \\
\text { particularly to the places near the close of } \\
\text { location were heavily affected. }\end{array}$ & $\begin{array}{l}\text { access was needed close to roads and } \\
\text { located not disturb to the } \\
\text { neighbourhoods }\end{array}$ \\
\hline 3 & $\begin{array}{l}\text { cleaning and cutting the } \\
\text { goats }\end{array}$ & $\begin{array}{l}\text { the butchers and } \\
\text { servants }\end{array}$ & $\begin{array}{l}\text { the process took places in a part of the } \\
\text { main corridor }\end{array}$ & $\begin{array}{l}\text { the places allocated inside the } \\
\text { kampong to make easy the process }\end{array}$ \\
\hline 4 & $\begin{array}{l}\text { 'gule' soup } \\
\text { the process took places in a part of the } \\
\text { main corridor and some communities } \\
\text { rented a house for cooking }\end{array}$ & $\begin{array}{l}\text { needed a realignment for the kitchen } \\
\text { and the selling places in the narrow } \\
\text { road }\end{array}$ \\
\hline 5 & $\begin{array}{l}\text { organizing the results of the } \\
\text { process into the carts }\end{array}$ & the sellers & $\begin{array}{l}\text { the carts were placed in deadends and } \\
\text { front of the houses }\end{array}$ & $\begin{array}{l}\text { a place to store had not been } \\
\text { functionally regulated for local } \\
\text { economic activity }\end{array}$ \\
\hline
\end{tabular}

Source: researcher, 2018

The typical activities everyday start from 2:00 am to 10:00 pm. People who involve were 'blantik' (people receive profits in trading goats), butchers, meat traders, seller of 'gule' soup and satay. These activities were centered on slaughterhouses. There were two function places: Mr. Hajj Toni's place and Mr.Yusup's place. The morning was a hectic time related to the processing and preparation for selling 'gule' soup. House terraces, slaughterhouses, kampong corridors became places to share activities and to role processing 'gule' soup.

Several researchers explained the designation of the third space in various versions, such as co-habitation space, transition space, and temporary public space. Researchers used different perspectives to explore different kampong spaces. Prayitno B. [17] explored the habits of the urban kampongs in a conservation perspective in a heritage city, its called as co-habitation space. Maliki NZ (2014) explained that it was a transitional space for those who return home or leave their kampongs[16]. Widharto[20] said it needs greening efforts, and many public spaces did not have green spaces. It could be concluded that the kampong space as a place to preserve the culture of its inhabitants and a comfortable place of transition. Bustaman had another meaning of urban kampong space according to the facts and reality that had been happening.

To express their socio-cultural interests, community were cooperative with one another, by sharing spaces, tools, and time to carry out their daily activities. The environment of the urban kampong space showed irregularities, especially in the nodes of local economic interests. The situation was very crowded, so compactness of space and activities occurs naturally and informally[15]. The sharing space explained the character of the space due to the impact of the socio-economic activities of the kampong, especially the processing and selling of 'gule' soup. Table: 1 above found essential recommendations for the improvement of kampong space so that the quality of the area would be more healthy and livable.

The phenomenon of the local economy was experiencing complexity and chaos in everyday life. Goat meat processing, sale of 'gule' soup, residents and actors, and places of activity showed overlapping activities, time, and place. Organizational arrangements run naturally and were not formally regulated, because they were owned by individuals. The concept of sharing 
was a subject of knowledge that could reflect events in several spaces. The sharing events on several terraces, in front of the former slaughterhouse, in front of public toilets, in the place of slaughtering goats, and including 'Gedong Sepuluh'. Among them, they shared in their place, time, role, and space, including migrants (boro traders).

\subsection{Structure of the Third Space of Bustaman,}

Informality was a characteristic of an urban kampong. It was grown without formal arrangements. Land ownership was owned by individuals, no by groups and even by the government. Generally, the status of the land was obtained through the inheritance of previous generations. The growth of urban kampong so occurs naturally and responds to urban physical changes. Residents of urban kampongs were low-income people and also the level of education.

Informality became the source of urban kampong space expression. The characteristic of Bustaman culture influences its kampong space reality. The spaces of Bustaman were irregular, efficient, and compact. Community spaces, public toilet facilities, and knots gather into social and cultural acculturations as a kampong of 'Gule'. The integration of activities influences the structure and pattern of Bustaman kampong space.

The third space had the meaning of sharing. Sharing in social, economic, and cultural aspects which encourage the firm of space character and pattern. The sharing was a key finding of this research. The sharing had meaning in the socio-economic context of the inhabitants and the physical condition of the environment in where they live. The sharing in everyday life make Bustaman was still survived and exist. Although in neighbouring there were still small conflicts in everyday life. A Sihombing (2004) showed that social and economic conflicts create chaos in urban kampongs[6]. Bustaman experienced the conflict, such as in front of slaughterhouses, terrace houses in the kampong, kampong corridors, in front of public toilets. They had patterns of adjustment and decisions in reducing conflicts in everyday life. These events can be seen in Fig. 3 .
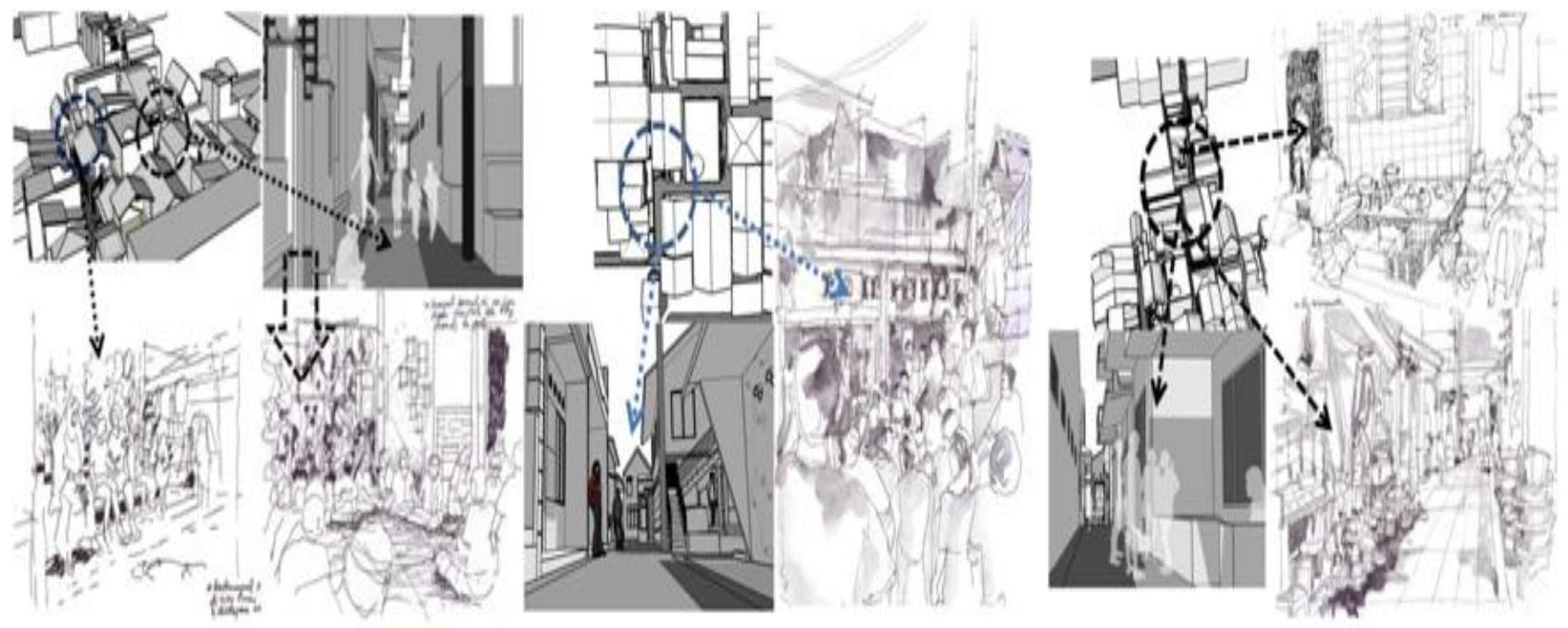

Fig. 3: Social and economic condition in Bustaman'slife.Source: researcher, 2018

Urban kampong space showed various meanings according to the context of the problem. Bustaman had a perspective derived from his people, not from the government or the private sector. The sharing was a concept knowledge of its inhabitants. Similar to the opinion of Prayitno B (2017) that the kampong space was a co-habitation space of its people[17]. The opinion of Maliki NZ (2014) that kampong space was a transition and expression for its residents[16]. Bunnel T [21]saw that changes in urban kampongs were caused by the market perspective, it is opposite from Bustaman residents idea.

Bustaman acknowledges the expression of the urban kampong as a 'gule' kampong. Wall murals in some part of kampong were a form of kampong existence expression in the process of urban modernization. Its transition had to improve the economic level of local community. Bustaman becomes an economic magnet for the community members and their surround. Cooking on the terrace, using public toilets, and gathering at the kampong corridors were the culture of Bustaman. Schematically it was in Fig. 4. 


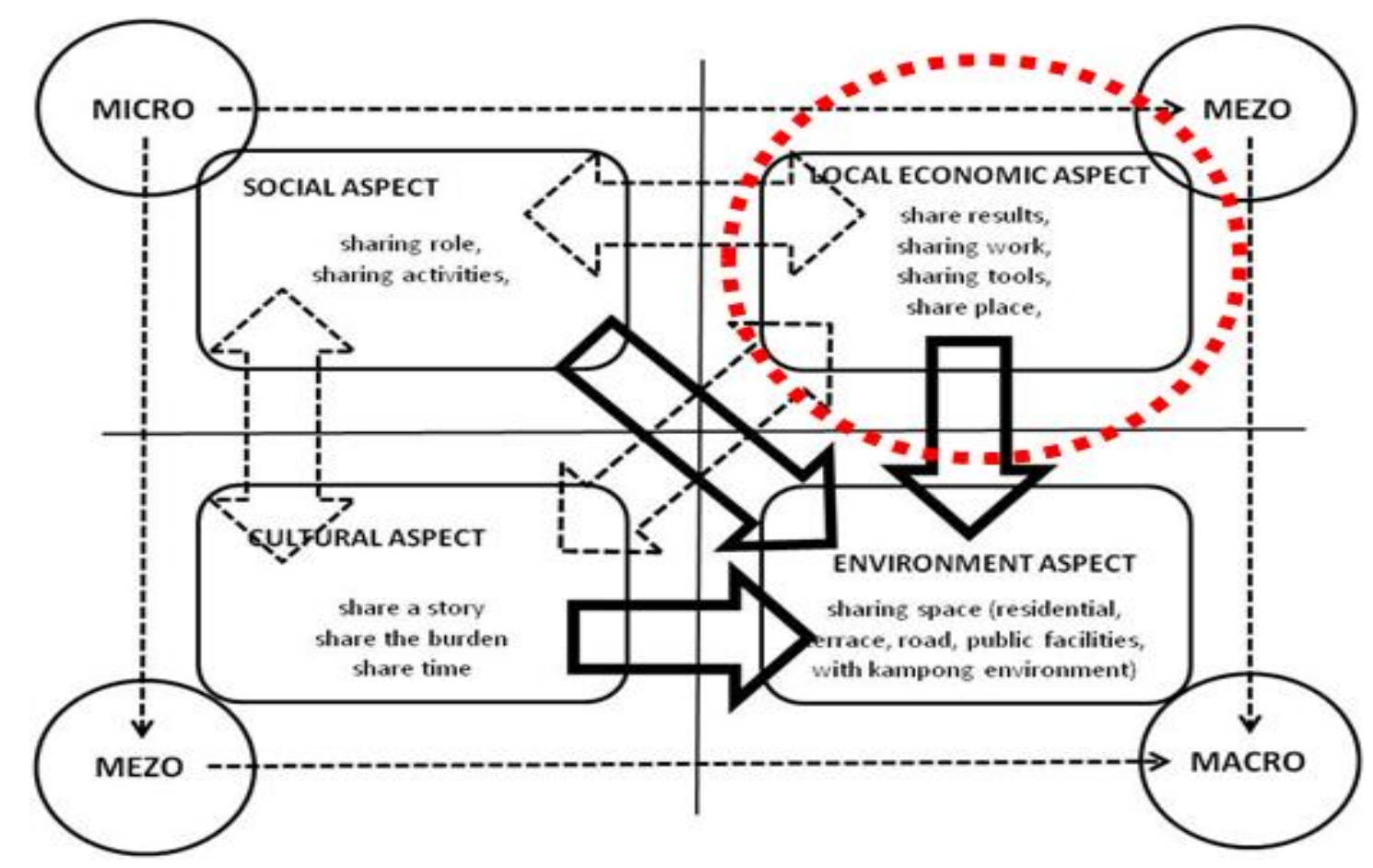

Fig. 4: Linkage of the sharing components in the 'theory of substance' structure. Source: researcher, 2019

The above scheme illustrates the sharing of life in social, economic and cultural aspects in the Bustaman. Sharing places, tools, roles and results are events in the kampong's local economic activities. The place of economic activity showed zoning according to the character of the business. They used the trading space according to their business capability and available space. The business of slaughtering goats greatly influenced the character of the kampong space, such as Mr. Hajj Toni's slaughterhouse. The kampong space becomes smelly, less clean, and unhealthy. Standing stalls reduces the width of the kampong's corridors. Cooking on the terrace created irregularity in the living environment.

In the social and cultural aspects also found the meaning of sharing. Unconsciously in local economic activities were divided into several roles and actors. The role as an inaugurator, butcher, 'gule' soup seller, and other supporting roles, several of them still had family ties. They took turns to bathe or wash in public toilets. Gathering on the corridors was done just for social relations. They were chatting together to share their stories today. They discussed the condition of their kampong to be better. They took care of their children and while being fed. The mosque as a place of prayer was also used for humanitarian social activities. All of these events had the meaning of sharing in social activities that become a habit of daily life.

\subsection{The Concepts of Sharing}

The local concept of "mangkat ndengkul mulih mikul" (selling without capital) was an expression of sharing for Bustaman community. 'Boro'traders (outsider traders) left the kampong without capital but went home with money from selling. The events of sharing roles and activities include sharing the profit of selling 'gule' soup. The processing goat into 'gule'soup cuisine showed the division of activities. Cuttinggoats, cooking 'gule' soup, and making spices were done in different places. The terrace was a space that has undergone a change in function and the kampong corridors were a place to cook 'gule' soup. The wheelbarrow tool for peddling was also only placed in dead-end alleys.

Goatslaughterhouses were places to share roles and functions in the management and sale of 'gulesoup'. Two goat slaughterhouses were drivers of local economic activity. Each place had different places and customers, local customers and migrant customers. The cities of Solo and Klaten were the origin of migrant customers.

Tension, clutter, and complexity were the effects of sharing roles and activities within the physical limitations of space. Less habitable and unhealthy housing along with unpleasant odour were weaknesses in the urban kampong space infrastructure. The socio-economic limitations of the residents and the potential of the local economy make the Bustaman physical environment far from the quality of a healthy and orderly environment. The sharing that occurs was unstructured and regular due to the spontaneous nature of occupants lives and the low quality of residential environments.

An empirical research approach produced knowledge of the concept. The findings of locality knowledge enrich the theory of space about urban kampongs. The sharing theory in the urban kampong realm was found in the Bustaman kampong that was based on local economies. The substantial theory could become a reference for urban kampong with the same character. Sharing means tolerance and had agreement where no regulates it firmly. The kindship and togetherness arrangements took place in the kampong.

Empirical knowledge about sharing became the third space concept of the Bustaman. The local economic activity was influences the Bustaman character, known as the Gule's kampong. Their uniqueness was able to survive within the limitations of space through the habits of life. Minor conflicts still exist in daily activities, but they could control them. The Javanese had a good tolerance culture and strong family characteristics. The smell of goats, dirty environment and less livable places were expressions of the reality of Bustaman where the inhabitants remain at home because of the demands of economic needs. 


\section{CONCLUSION:}

Sharing was local knowledge of Bustaman based on locale economic activities to survive in urban modernization. 'Gule' soup was the core of economic activities in the kampong. The business life of 'gule' soup was supported by its culture and social structure character. Local economic activities make the physical condition of the urban space had decreased the quality of the environment. The smelly and unhealthy environment was the physical condition of the kampong space. Therefore assistance and guidance in maintaining a healthy environment for residents were necessary. Sharing was a local knowledge that exists in the social, cultural, and physical aspects of Bustaman's third space. The social and culture of residents influence of locale economic activities life. That aspect could be studied more deeply through other methods and perspective. The interiority of space in kampong was interesting topic.

The expressions and community's behaviour in solving life problems in urban kampong was unique. By sharing all of the issues of life were solved. Sharing space was unique when placed in a dense and limited area, but had a high activity and diversity of interests. There were conflict and togetherness in the activities of daily life, which had an impact on space and its environmental character, which was spontaneous, irregular, but efficient.

\section{CONTRIBUTION TO KNOWLEDGE:}

The uniqueness of Bustaman provided enrichment theory in the realm of knowledge of urban kampong architecture. The knowledge of urban culture based on local economic potential. The findings of this study were illustrated how the Bustaman survives in order to continue to exist in the process of urban change. The kampong space was experienced spatial tension related to dynamics of area spatial, the cohesion of interaction social, and easy to access. The public spaces were also experienced temporary changes and overcapacity to meet the needs of daily life for its inhabitants.

\section{ACKNOWLEDGEMENT}

The author would like to thank the Dean of the Faculty of Engineering, the University of Diponegoro who provided financial support for this research with the contract number: 2689/UN7.3.3/PG/2018. The author would also like to thank Bustaman community leaders and residents who provided information about their kampong.

\section{Conflict of Interest:}

The authors declare no conflict of interest

\section{REFERENCES}

[1] J. Santoso, "Understanding urban transformation in Asia: case study of Jakarta," Journal of Tata Loka, vol. 15, no. 2 , 2013.

[2] B. Setiawan, "Kampung Kota dan Kota Kampung: Tantangan Perencanaan Kota di Indonesia. Pidato Pengukuhan Jabatan Guru Besar dalam Ilmu Perencanaan Kota.” Yogyakatra: Universitas Gajah Mada, 2010.

[3] M. S. Roychansyah and A. Diwangkari, "Kampung Oriented Development Model: A Rapid Appraisal of Local Communities," in Proceeding of CIB-W110 Meeting and Conference "Sustainable Slum Upgrading in Urban Areas, 2009, pp. 119-134.

[4] L. Winayanti and H. C. Lang, "Provision of urban services in an informal settlement: a case study of Kampung Penas Tanggul, Jakarta," Habitat International, vol. 28, no. 1, pp. 41-65, 2004.

[5] F. Colombijn, "Toooot! Vroooom! The Urban Soundscape in Indonesia," Sojourn: Journal of Social Issues in Southeast Asia, vol. 22, no. 2, pp. 255-272, 2007.

[6] A. Sihombing, "The transformation of Kampungkota: Symbiosys Between Kampung and Kota," A Case Study from Jakarta, Universitas Indonesia, Jakarta, 2004.

[7] A. Sutandyo and Buchholz, "Collective activity as a traditional knowledge behind the physical design: Case of urban kampungs in indonesia," Planum. The Journal of Urbanism, vol. 1, no. 26, pp. 1-13, 2013.

[8] B. Sudarwanto, G. Hardiman, and A. B. Sardjono, "Bustaman, a Cultural Urban Kampong Based on Culinary Gule as Response to Urban Changes," TATALOKA, vol. 21, no. 3, 2019.

[9] K. C. Desouza and T. H. Flanery, "Designing, planning, and managing resilient cities: A conceptual framework," Cities, vol. 35, pp. 89-99, 2013.

[10] C. Poolkhet et al., "Social network analysis of cattle movement in Kampong Cham, Kampong Speu and Takeo, Cambodia," Acta tropica, vol. 159, pp. 44-49, 2016.

[11] A. G. Flor, "ICT and poverty: The indisputable link," in SEARCA, paper for the Third Asian Development Forum on "Regional Economic Cooperation in Asia and the Pacific", Asian Development Bank, 2001, pp. 11-14.

[12] A. Suprapti, N. H. Kistanto, E. E. Pandelaki, and D. Indrosaptono, "Control of spatial protection in Kauman Semarang," Journal of Architecture and Urbanism, vol. 41, no. 4, pp. 268-277, 2017.

[13] H. Lefebvre and D. Nicholson-Smith, The production of space, vol. 142. Oxford Blackwell, 1991.

[14] Sudaryono, "Perencanaan Kota Berbasis Kontradiksi: Relevansi Pemikiran Henri Lefebvre dalam Produksi Ruang Perkotaan Saat Ini,” Journal of Regional and City Planning, vol. 19, no. 1, pp. 1-12, 2008.

[15] N. Hamidah, R. Rijanta, B. Setiawan, and M. A. Marfai, “Kampung' as a Formal and Informal Integration Model (Case Study: Kampung Pahandut, Central Kalimantan Province, Indonesia)," in Forum Geografi, 2017, vol. 31, no. 1, pp. 43-55.

[16] N. Z. Maliki, A. Abdullah, and A. Bahauddin, "Recalling the transitional space: City home and kampung home," ProcediaSocial and Behavioral Sciences, vol. 170, pp. 605-612, 2015. 
[17] B. Prayitno, "Co-habitation Space: A Model for Urban Informal Settlement Consolidation for the Heritage City of Yogyakarta, Indonesia," Journal of Asian Architecture and Building Engineering, vol. 16, no. 3, pp. 527-534, 2017.

[18] N. H. M. Hussain and H. Byrd, “'Balik Kampong': Is Malaysia Facing the Trends of De-Urbanization?,” International Journal of the Malay World and Civilisation (Iman), vol. 4, no. 2016, pp. 35-43, 2016.

[19] R. Damayanti and F. Kossak, "Extending Kevin Lynch's concept of imageability in third space reading; case study of Kampungs, Surabaya--Indonesia," A| Z ITU Journal of the Faculty of Architecture, vol. 13, no. 1, pp. 57-67, 2016.

[20] S. D. Widharto, N. Muchlis, S. H. Laksono, and P. Setijanti, "Design concept for green public space in kampong," Journal of Architecture and Urbanism, vol. 39, no. 2, pp. 116-123, 2015.

[21] T. Bunnell, "Kampung rules: landscape and the contested government of urban (e) Malayness," Urban studies, vol. 39, no. 9, pp. 1685-1701, 2002.

\section{Author Biography:}

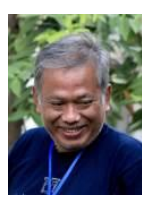

Budi Sudarwanto,

Associate Professor of Architecture Department of Faculty Engineering Diponegoro University. Born in Magelang, Central Java, August 4, 1964. Several studies were carried out in the realm of sustainable urban architecture. Member of the Indonesian Institute of Architects Chapter in Central Java. Some received research grants from the Diponegoro University Faculty of Engineering and the Diponegoro University Research and Community Service Institute. 